\title{
Dermal denticles as a tool to reconstruct shark communities
}

\author{
Erin M. Dillon ${ }^{1, *}$, Richard D. Norris ${ }^{2}$, Aaron O'Dea ${ }^{1}$ \\ ${ }^{1}$ Smithsonian Tropical Research Institute, Balboa, Republic of Panama \\ ${ }^{2}$ Scripps Institution of Oceanography, University of California, San Diego, La Jolla, CA 92037, USA
}

\begin{abstract}
The last $50 \mathrm{yr}$ of fisheries catch statistics and ecological surveys have reported significant decreases in shark populations, which have largely been attributed to human activities. However, sharks are challenging to census, and this decline likely pre-dated even the longest fishery-dependent time series. Here we present the first use of dermal denticles preserved in reef sediments as a novel tool to reconstruct shark communities. We first built a dermal denticle reference collection and conducted a morphometric analysis of denticle characters to relate denticle form to taxonomy, shark ecology, and denticle function. Denticle morphology was highly variable across the body of an individual shark and between taxa, preventing species- or genus-level identification of isolated denticles. However, we found that denticle morphology was strongly correlated with shark ecology, and morphometric analysis corroborated existing functional classifications. In a proof of concept, we extracted 330 denticles from modern and fossil reef sediments in Bocas del Toro, Panama and found them to be morphologically diverse and sufficiently well-preserved to allow classification. We observed a high degree of correspondence between the denticles found in the sediments and the sharks documented in the region. We therefore propose that (1) denticle assemblages in the recent fossil record can help establish quantitative pre-human shark baselines and (2) time-averaged denticle assemblages on modern reefs can supplement traditional surveys, which may prove especially valuable in areas where rigorous surveys of sharks are difficult to perform.
\end{abstract}

KEY WORDS: Dermal denticle $\cdot$ Functional morphology $\cdot$ Shark $\cdot$ Paleoecology $\cdot$ Baseline

\section{INTRODUCTION}

Understanding the temporal and spatial dynamics of shark communities and how they are affected by human activities is challenging (Ferretti et al. 2010, Nadon et al. 2012, Roff et al. 2016). Both fisherydependent and independent assessments reveal that shark populations worldwide have suffered significant declines over the past several decades due to overfishing and habitat degradation (Myers \& Worm 2003, Ferretti et al. 2010). Pelagic longline surveys and landing statistics from fisheries in the northwest Atlantic reported 49 to $89 \%$ declines in catch rates of 18 shark species between 1985 and 2000 (Baum et al. 2003), while even higher losses of up to $99 \%$ were found in the Gulf of Mexico between the 1950s and the late 1990s (Baum \& Myers 2004). This decline has likely continued since. Diver and video surveys have examined patterns of reef-associated species across oceanographic, habitat, and anthropogenic gradients as well as in space-for-time analyses (Sandin et al. 2008, Espinoza et al. 2014, Williams et al. 2015). For example, top predator biomass was found to be 5 to 15 -fold higher at unfished islands in the Line Islands as compared to populated, fished islands (DeMartini et al. 2008). However, these records are sporadic, limited in detail or taxonomic resolution, and only date back half a century (Odum \& Odum 1955, Baum \& Myers 2004, Ward \& Myers 2005, Ferretti et al. 2008, Ward-Paige et al. 2010b). Cryptic behavior, rarity, and 


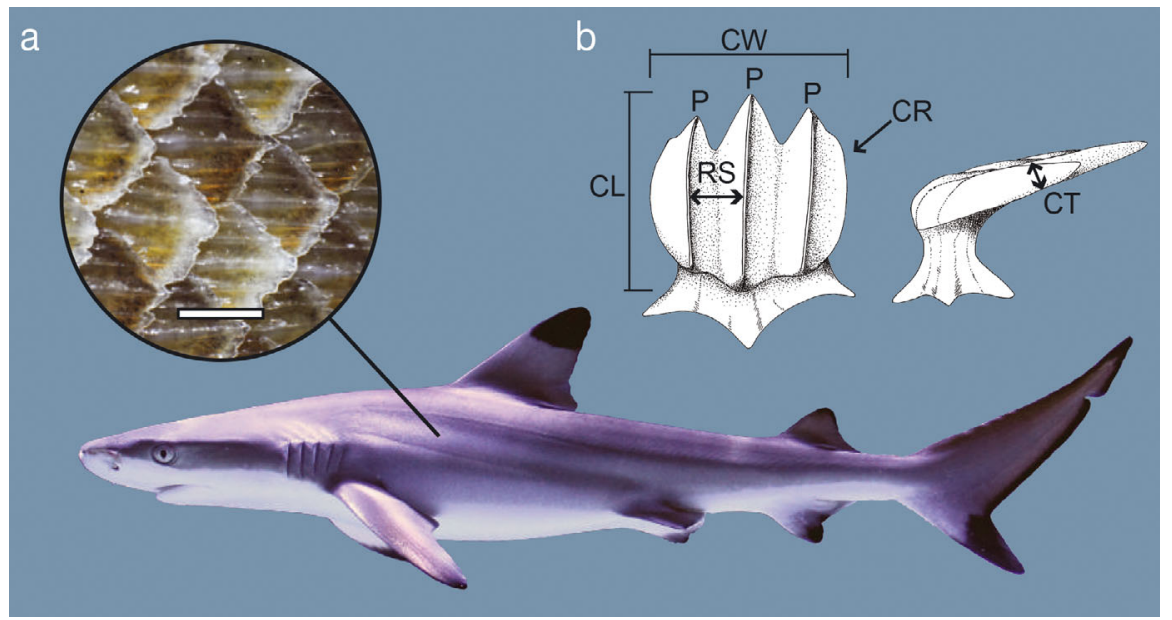

Fig. 1. (a) A blacktip reef shark Carcharhinus melanopterus with inset dermal denticles. Scale bar $=200 \mu \mathrm{m}$. Photo adapted from Kakidai/Wikimedia Commons/CC-BY-SA-3.0. (b) Illustration of the dorsal and lateral view of a dermal denticle from the body of a lemon shark Negaprion brevirostris, showing the morphological measurements taken with an ocular micrometer and important landmarks. CR: crown; CL: crown length; CT: crown thickness; CW: crown width; P: peak; RS: ridge spacing

diurnal and seasonal movement patterns prevent sharks from being meaningfully censused in many regions (Sale \& Douglas 1981, MacNeil et al. 2008, Ward-Paige et al. 2010a, McCauley, et al. 2012a). Time series or replicated surveys have also shown conflicting trends for the same area depending on the survey method used and its associated biases (Burgess et al. 2005, Ward-Paige, et al. 2010a, Nadon et al. 2012), leading to misrepresentations of the status of shark populations and their unfished baseline conditions (Heupel et al. 2009, Rizzari et al. 2014).

To address this problem, we explored whether dermal denticles, the small, tooth-like scales covering the skin of nearly all elasmobranchs (Fig. 1), can be used as a tool to reconstruct shark communities on coral reefs. Denticles are several orders of magnitude more abundant than teeth on a living shark and are continually shed (Reif 1985a, Compagno et al. 2005). Like teeth, denticles preserve well and have a long fossil record (Janvier 1996, Sansom et al. 2012), potentially providing a unique opportunity to retrospectively 'survey' modern and pre-exploitation shark assemblages. In this paper, we (1) review denticle morphology, taxonomy, and function; (2) present a reference collection of shark dermal denticles; (3) introduce a technique to extract and identify denticles from modern and fossil reef sediments; and (4) discuss the limitations and potential applications of the approach.

\section{BACKGROUND: DERMAL DENTICLE MORPHOLOGY, TAXONOMY, AND FUNCTION}

Dermal denticles are composed of a dentine and enameloid crown attached to a basal plate, which is anchored to the skin by collagen fibers (Applegate
1967). Denticles display considerable variation in crown shape, size, and thickness (Figs. 1 \& 2). Crowns can possess ridges of varying length, height, orientation, and spacing and may or may not terminate in an equal number of peaks (Tway 1979, Reif 1985a, Raschi \& Musick 1986, Raschi \& Tabit 1992) (Fig. 2).

Individual sharks possess multiple types of denticles arranged systematically along their bodies (Reif 1985a, Raschi \& Tabit 1992, Bargar \& Thorson 1995, Salini et al. 2007), and denticle morphotypes can be shared across taxa (Reif 1982, 1985a, Muñoz-Chápuli 1985a, Tanaka et al. 2002, Gilligan \& Otway 2011). Denticle morphology can also vary with sex (Crooks et al. 2013) and ontogeny (Reif 1985a). Only in a few cases can isolated denticles be identified beyond the family level (Reif 1985a, Mello et al. 2013, Ferrón et al. 2014). Conversely, denticle morphology appears to be more closely linked to the ecological guild of the shark species to which it belongs as well as to the specific function it plays on the shark's body (Reif 1978, 1985b, Raschi \& Musick 1986, Raschi \& Tabit 1992).

Five major functional groups of dermal denticles have thus far been established: (1) drag reduction, (2) abrasion strength, (3) defense, (4) luminescence and (5) generalized functions (Reif 1982, 1985a, 1985b, Raschi \& Tabit 1992). In general terms, fast, pelagic sharks are covered almost entirely by thin, highly ridged drag reduction denticles, while demersal sharks possess thick, smooth abrasion strength denticles that provide protection from the substrate (Reif 1985a, Raschi \& Tabit 1992). However, abrasion strength denticles can also occur in small areas of the head and leading edges of the fins on non-demersal sharks (Reif 1985a, Bargar \& Thorson 1995, Motta et al. 2012). Other demersal and schooling species pos- 
a 1

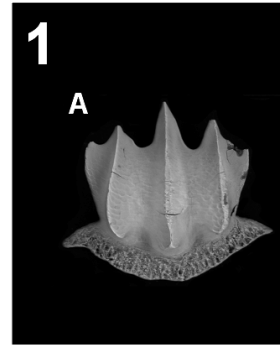

B

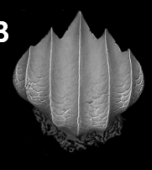

C

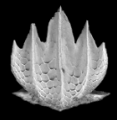

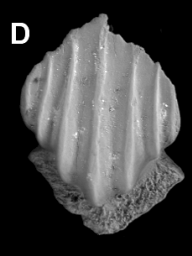

E

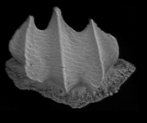

H

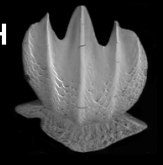

$\mathbf{F}$<smiles>C1CC2CC3CC1CC2C3</smiles>

G
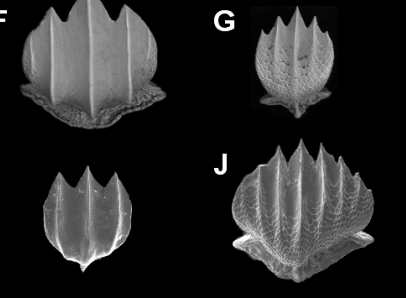

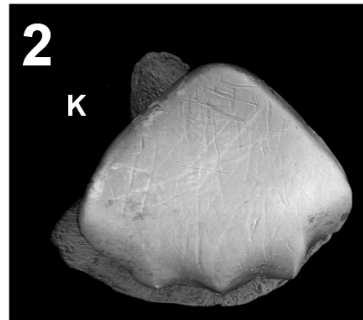

M

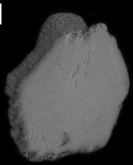

0

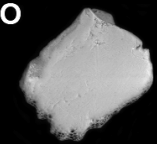

$\mathbf{N}$

\section{$\mathbf{N}$}

$\mathbf{L}$
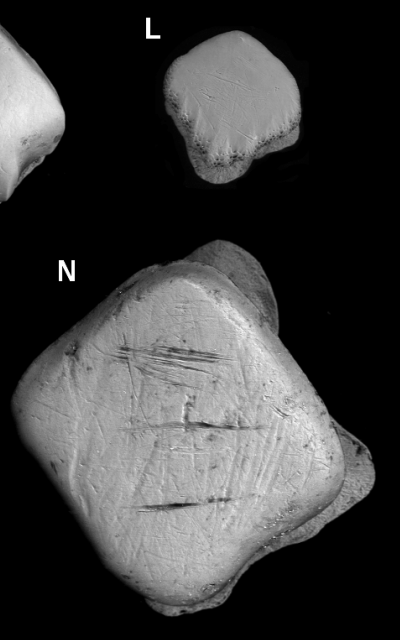

\section{3}

$\mathbf{P}$
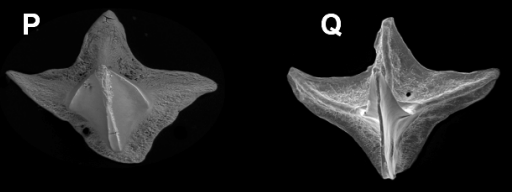

$\mathbf{R}$

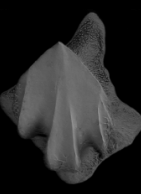

S
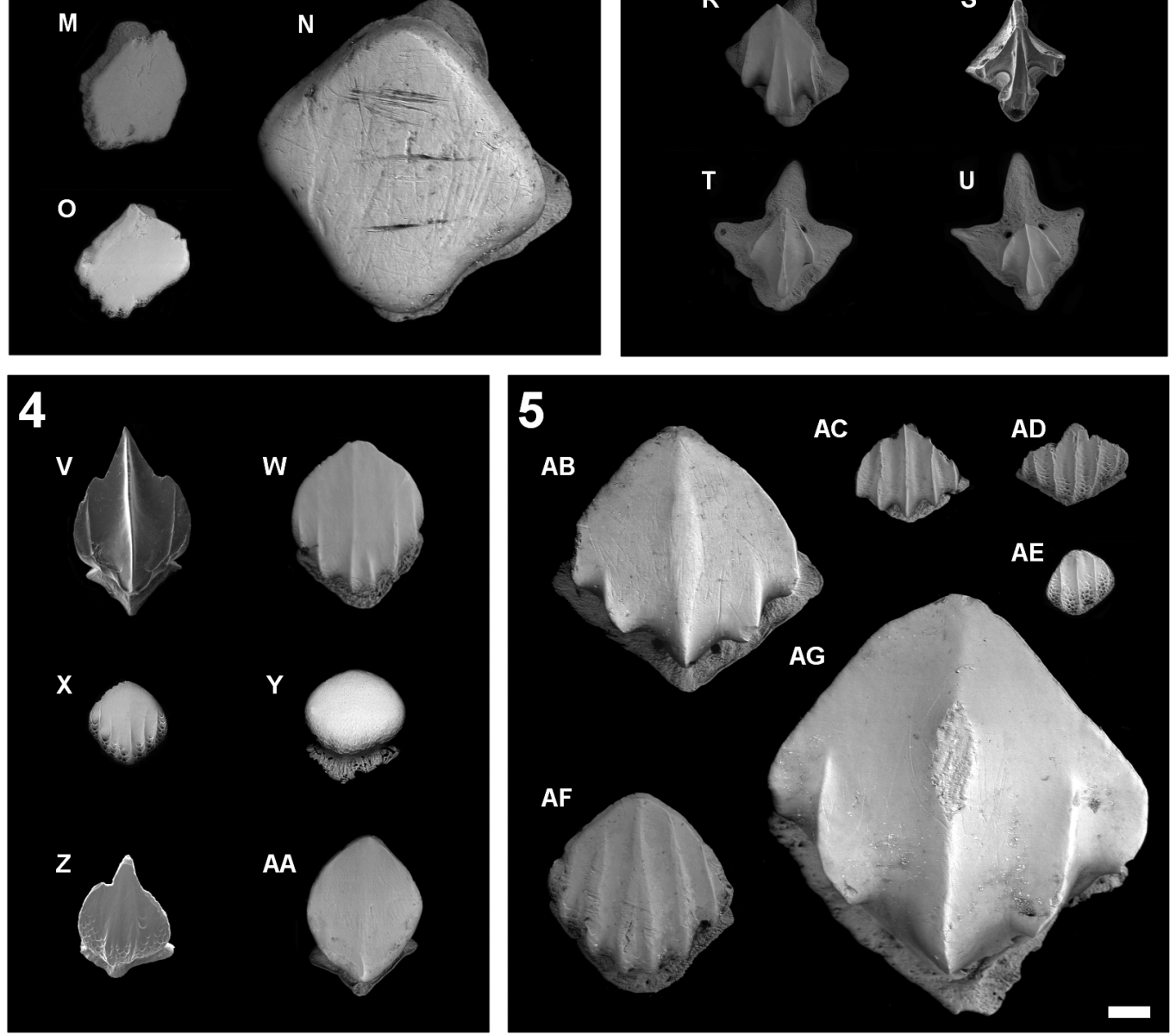

Fig. 2. Scanning electron microscope images of dermal denticles from the reference collection demonstrating morphological variation across functional morphotypes and shark families.

(a) Examples of each functional morphotype: (1) drag reduction; (2) abrasion strength; (3) defense; (4) generalized functions; (5) ridged abrasion strength. The luminescence morphotype is not shown due to its rarity in the reference collection, which focused on shallow, coastal species. 
b Family Ginglymostomatidae

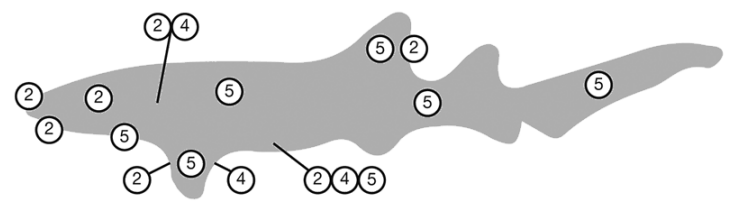

Family Carcharhinidae, excluding tiger shark (Galeocerdo cuvier)

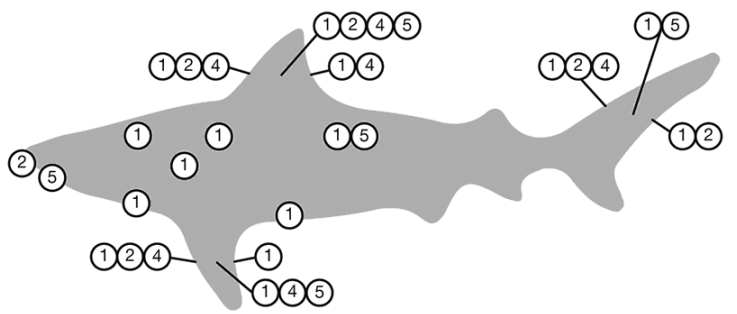

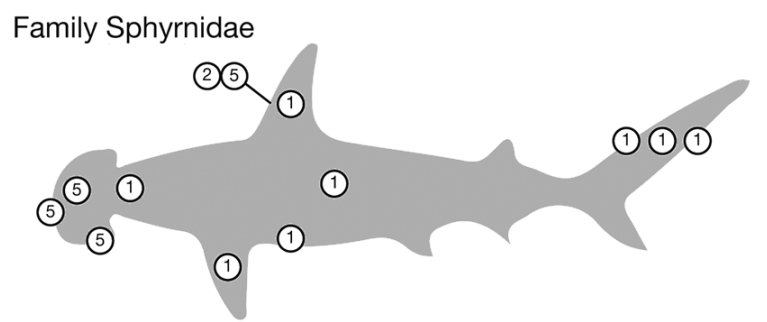

Family Carcharhinidae, tiger shark (Galeocerdo cuvier)

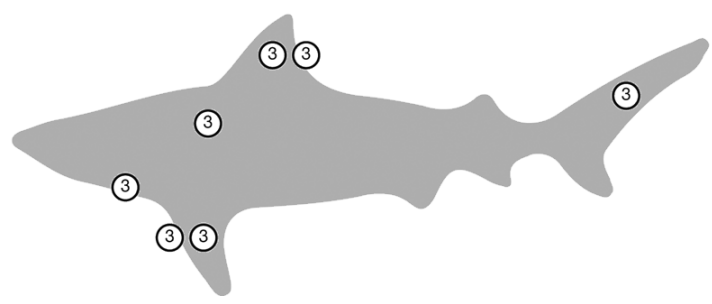

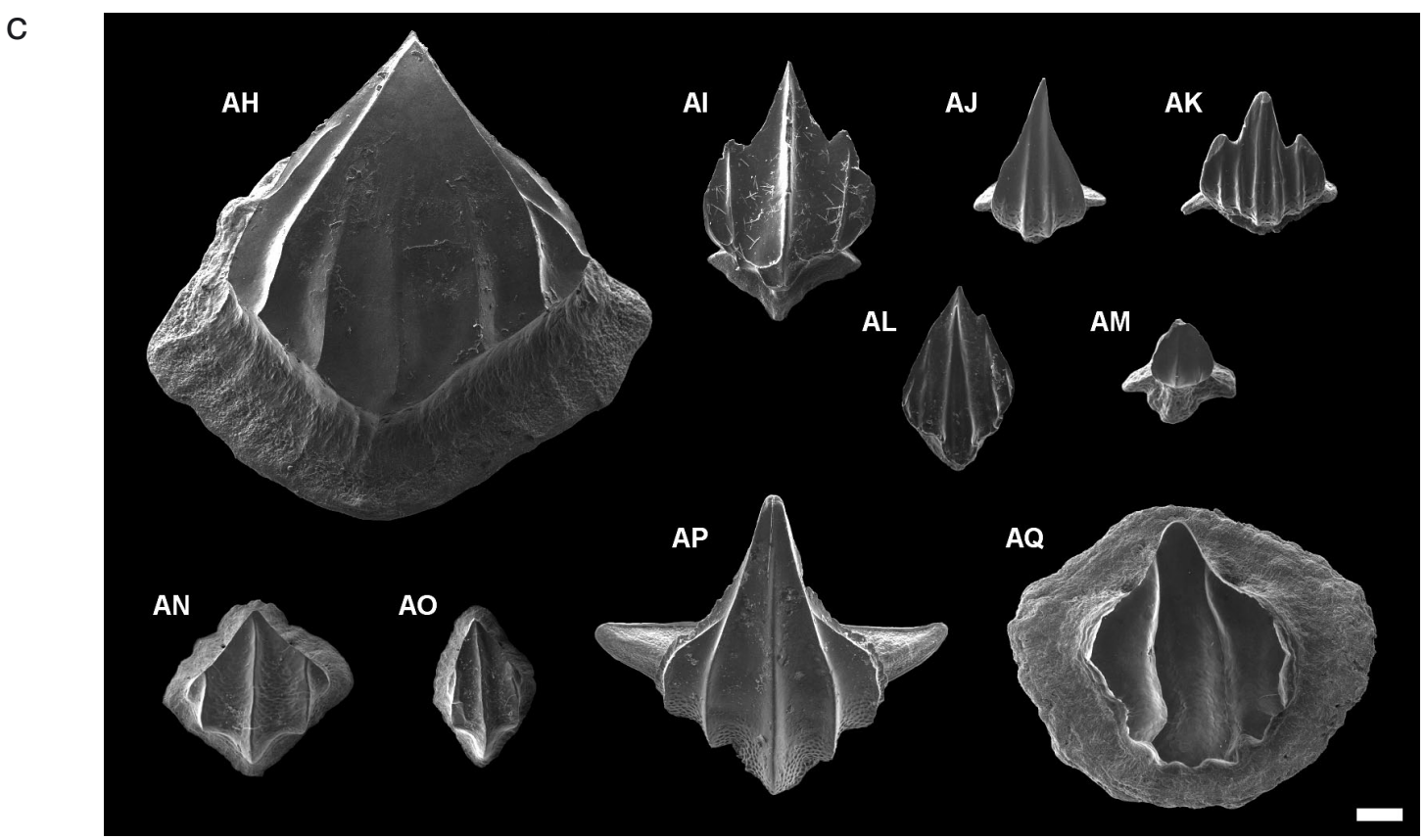

Fig. 2 (continued)

(b) Distribution of functional morphotypes across the bodies of 3 reef-associated shark families. Numbers correspond to boxes in panel (a). Note that the tiger shark Galeocerdo cuvier is characterized by defense type denticles, unlike the other species sampled in Carcharhinidae.

(c) Scanning electron microscope images of denticles from mesopelagic and pelagic families included in the reference collection. Many are visually distinct from the denticles of the reef-associated families sampled. Scale bars $=100 \mu \mathrm{m}$.

Species and anatomical position of each denticle (see Fig. 3 for explanation of sample location codes following the species names): (A) Carcharhinus leucas, B2; (B) Carcharhinus falciformis, B2; (C) Sphyrna lewini, B2; (D) Carcharhinus acronotus, C2; (E) Carcharhinus perezi, B2; (F) Negaprion brevirostris, B3; (G) Sphyrna mokarran, P2; (H) Carcharhinus obscurus, B2; (I) Alopias vulpinus, B3; (J) Sphyrna zygaena, H2; (K) Ginglymostoma cirratum, B3; (L) Carcharhinus galapagensis, H1; (M) Sphyrna tiburo, D1; (N) Ginglymostoma cirratum, H1; (O) Carcharhinus obscurus, D1; (P) Galeocerdo cuvier, B2; (Q) Squalus acanthias, B2; (R) Galeocerdo cuvier, C1; (S) Squalus cubensis, B2; (T) Galeocerdo cuvier, C2; (U) Galeocerdo cuvier, D2; (V) Heptranchias perlo, H2; (W) Negaprion brevirostris, D2; (X) Carcharhinus falciformis, D2; (Y) Carcharhinus falciformis, D3; (Z) Mustelus canis, D3; (AA) Ginglymostoma cirratum, D3; (AB) Ginglymostoma cirratum, P2; (AC) Carcharhinus limbatus, nostril; (AD) Sphyrna couardi, eye; (AE) Sphyrna lewini, H1; (AF) Triaenodon obesus, C2; (AG) Ginglymostoma cirratum, B2; (AH) Centrophorus granulosus, B3; (AI) Heptranchias perlo, B2; (AJ) Mustelus canis, B2; (AK) Mustelus canis, B3; (AL) Squalus cubensis, C2; (AM) Pristis perotteti, B2; (AN) Pseudocarcharias kamoharai, B2; (AO) Pseudocarcharias kamoharai, C2; (AP) Scyliorhinus retifer, B2; (AQ) Squatina dumeril, B2 
sess spiny defense denticles, which are hypothesized to deter the settlement of ectoparasites and epibionts (Applegate 1967, Reif 1985a). Bioluminescent mesopelagic sharks possess luminescence denticles that permit light emission from photophores on the skin (Reif 1985b, Raschi \& Tabit 1992). Generalized functions denticles are widely distributed across taxa (Reif 1985a). Intermediate forms between these groups also exist (Reif 1985a, Raschi \& Tabit 1992).

\section{METHODS}

\section{Dermal denticle reference collection}

Given the diverse spectrum of denticle morphology, our aim was to facilitate the identification of isolated denticles extracted from sediments by (1) morphometrically categorizing denticles and (2) determining the extent to which the occurrences of established denticle morphotypes are constrained with taxonomic and ecological groups of sharks. To do so, we first built a reference collection of modern shark dermal denticles from the ichthyology collection at the Smithsonian National Museum of Natural History and catches by fishermen in Bocas del Toro and Colón, Caribbean Panama. We focused on tropical coastal and reefassociated sharks, with a total of 37 species representing 16 families (Table 1). Given ontogenetic variation in denticle morphology, the largest individuals in the museum's collection were sampled when possible, although many of the specimens were juveniles (Table 1). From each specimen, $\sim 1 \mathrm{~cm}^{2}$ pieces of skin were excised from standardized locations along the body (Fig. 3). Excised tissues were immersed in a $1 \%$ sodium hypochlorite solution until the denticles detached from the skin. Between 1 and 4 denticles were selected for morphometric analysis from each of the 191 skin samples collected, for a total of 215 denticles (Table S1 in the Supplement at www.int-res.com/ articles/suppl/m566p117_supp.pdf). More than 1 denticle was characterized per skin sample when there were multiple visually distinct morphological forms present. All denticles were imaged via light and scanning electron microscopy.

\section{Morphometric analysis of the dermal denticle reference collection}

Each denticle in the reference collection was assigned to one of 6 functional morphotypes following Reif (1985a): drag reduction, abrasion strength, ridged abrasion strength, defense, luminescence, and generalized functions (Fig. 2, Table S1). Abrasion strength denticles were divided into 2 sub-categories to account for differences in proposed hydrodynamic function due to the presence of ridges (Raschi \& Tabit 1992). To explore the correspondence between denticle morphology and shark taxonomy and ecology, we collected morphometric character data from each denticle in the reference collection. Crown shape, size, and thickness, the number and types of peaks, and the presence, length, orientation, and spacing between ridges were recorded (Fig. 1, Tables $2 \& \mathrm{~S} 1$ ). Character selection was based on proposed functional significance (e.g. Reif \& Dinkelacker 1982), previous studies (Tway 1979, Raschi \& Musick 1986, Salini et al. 2007, Ferrón et al. 2014), and observed variation in denticle morphology. Character data was ordinated using principal component analysis (PCA; R Core Team 2014), and each categorical character was included in the ordination as multiple isolated dichotomous variables. This allowed us to examine

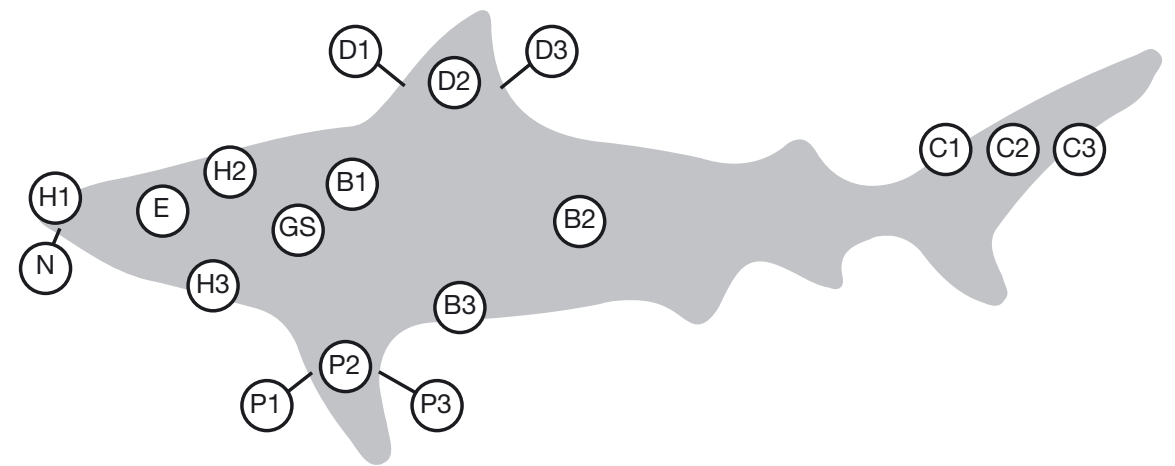

Fig. 3. Locations of skin samples for the dermal denticle reference collection. All anatomical positions are shown, although samples from each were not taken for every family. The B2, C2, D2, and P2 regions were selected as standard sampling positions, and auxiliary positions were haphazardly sampled in each family to better characterize variation in denticle morphology across the body (see Table S2 in the Supplement). All positions correspond to sampling locations from previous studies to allow comparison. B: body; C: caudal fin; D: dorsal fin; E: eye; GS: gill slit; H: head; N: nostril; P: pectoral fin 


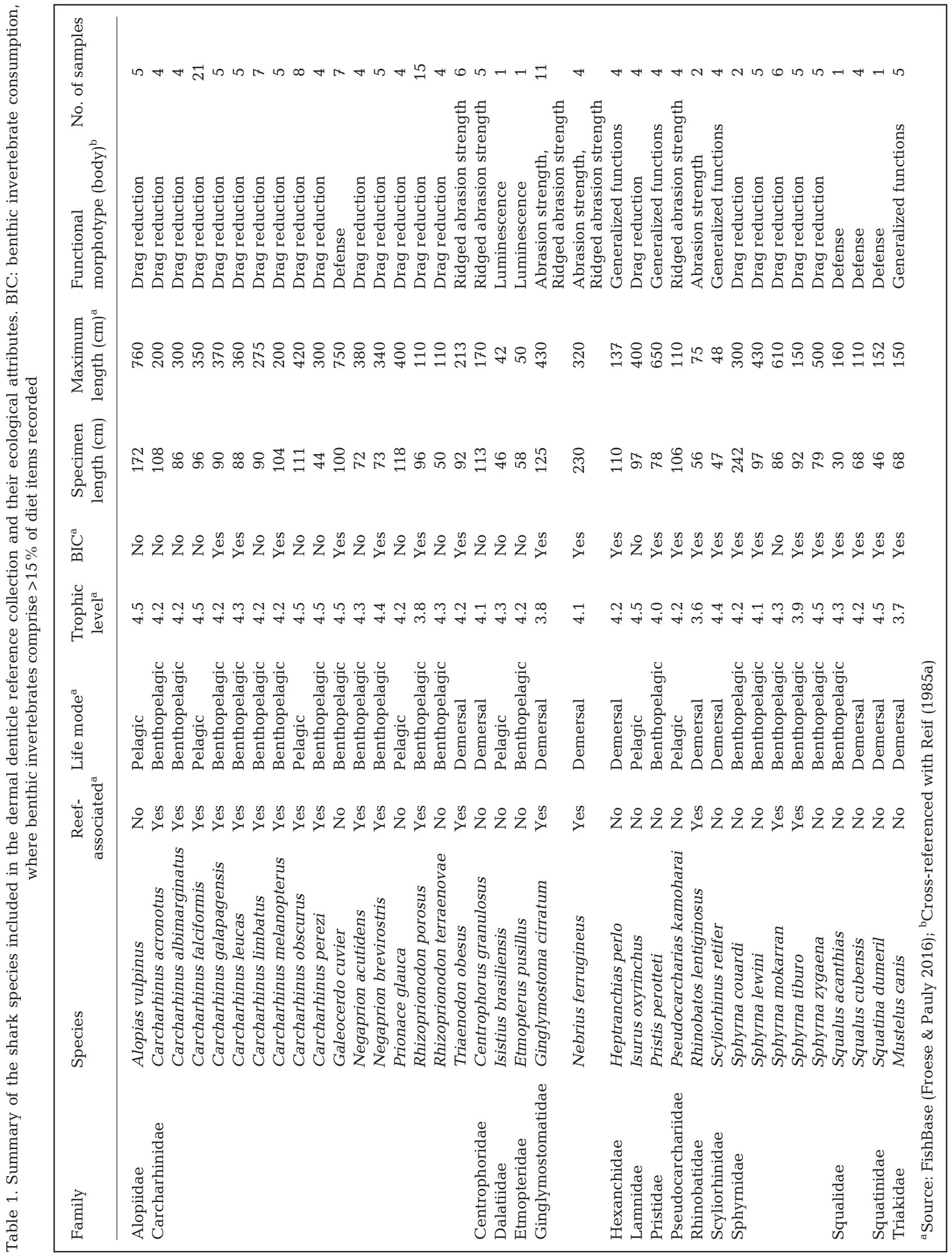


Table 2. Dermal denticle characters measured for the morphometric analysis. See Figs. 1 \& 2 for definitions and examples of traits

\begin{tabular}{|c|c|c|}
\hline & Character & $\begin{array}{l}\text { Examples } \\
\text { from Figs. } 1 \& 2\end{array}$ \\
\hline Crown shape & $\begin{array}{l}1 \text { Circular or elliptical } \\
2 \text { Lanceolate or teardrop-shaped } \\
3 \text { Diamond-shaped, square, or } \\
\text { triangular } \\
4 \text { Cruciform or arrow-shaped } \\
5 \text { Lobed on all sides }\end{array}$ & $\begin{array}{l}\text { C, H, Y } \\
\text { V, AJ, AP } \\
\text { K, N, AG } \\
\text { Q, R, T } \\
-\end{array}$ \\
\hline Crown size & $\sqrt{ }($ length $(C L) \times$ width $(C W))$ & See Fig. 1 \\
\hline $\begin{array}{l}\text { Crown thickness } \\
\text { ratio }\end{array}$ & $\begin{array}{l}\sqrt{ }(\text { length }(\mathrm{CL}) \times \text { width }(\mathrm{CW})) / \\
\text { thickness }(\mathrm{CT})\end{array}$ & See Fig. 1 \\
\hline $\begin{array}{l}\text { Crown micro- } \\
\text { structures }\end{array}$ & $\begin{array}{l}0 \text { Absent } \\
1 \text { Present }\end{array}$ & $\begin{array}{l}\mathrm{D}, \mathrm{I}, \mathrm{AB} \\
\mathrm{H}, \mathrm{J}, \mathrm{L}\end{array}$ \\
\hline $\begin{array}{l}\text { Number of } \\
\text { peaks }\end{array}$ & $\begin{array}{l}0 \text { Single peak } \\
1>1 \text { peak }\end{array}$ & $\begin{array}{l}\mathrm{X}, \mathrm{AC}, \mathrm{AO} \\
\mathrm{A}, \mathrm{E}, \mathrm{V}\end{array}$ \\
\hline Peak type & $\begin{array}{l}1 \text { Rounded peaks or single } \\
\text { V-shaped peak } \\
2 \text { Distinct serrated peaks } \\
3 \text { Scalloped (unpronounced, } \\
\text { short) peaks } \\
4 \text { Peak edges curve inward } \\
\text { to form single tip (teardrop) }\end{array}$ & $\begin{array}{l}\text { W, AD, AF } \\
\text { F, G, H } \\
\text { D, AD } \\
\text { S, V, Z }\end{array}$ \\
\hline $\begin{array}{l}\text { Presence of } \\
\text { ridges }\end{array}$ & $\begin{array}{l}0 \text { No ridges } \\
1 \geq 1 \text { ridge }\end{array}$ & $\begin{array}{l}\mathrm{K}, \mathrm{M}, \mathrm{N} \\
\mathrm{B}, \mathrm{AE}, \mathrm{AK}\end{array}$ \\
\hline Ridge length & $\begin{array}{l}1 \text { Incomplete, medially- } \\
\text { reduced ridges } \\
2 \text { Complete ridges }\end{array}$ & $\begin{array}{l}\text { W, Z, AG } \\
A, D, A D\end{array}$ \\
\hline $\begin{array}{l}\text { Upward-pointing } \\
\text { medial spine }\end{array}$ & $\begin{array}{l}0 \text { Absent } \\
1 \text { Present }\end{array}$ & $\begin{array}{l}\text { C, AF, AN } \\
P, Q, S\end{array}$ \\
\hline $\begin{array}{l}\text { Ridge } \\
\text { orientation }\end{array}$ & $\begin{array}{l}1 \text { Parallel ridges } \\
2 \text { Sub-parallel ridges }\end{array}$ & $\begin{array}{l}\mathrm{B}, \mathrm{F}, \mathrm{AC} \\
\mathrm{U}, \mathrm{AF}, \mathrm{AI}\end{array}$ \\
\hline Ridge spacing & $\begin{array}{l}0 \text { No ridge spacing } \\
11 \text { to } 100 \mu \mathrm{m} \text { ridge spacing } \\
2>100 \mu \mathrm{m} \text { ridge spacing }\end{array}$ & $\begin{array}{l}\mathrm{O}, \mathrm{Y}, \mathrm{AA} \\
\mathrm{G}, \mathrm{I}, \mathrm{AE} \\
\mathrm{AG}, \mathrm{AH}, \mathrm{AI}\end{array}$ \\
\hline
\end{tabular}

the effect of each variable separately in the ordination as opposed to solely the aggregate character categories. Ecological attributes of each species (life mode, reef-association, trophic position, benthic invertebrate consumption, and maximum length; Table 1) were added a priori to observe relationships between denticle characters and shark ecology. For each strongly explanatory character in the PCA, regressions or 1-way ANOVAs with Tukey's HSD post-hoc tests were used to evaluate pairwise differences between groups and assess correlations with shark ecology. Character frequency of occurrence was calculated for each shark family and functional morphotype to describe the range of variability within each group.

\section{Proof of concept: extracting dermal denticles from modern and fossil sediments}

To explore the application of dermal denticle analysis to reconstruct shark communities, we collected sediments from modern reefs and a mid-Holocene fossil reef in Bocas del Toro, Panama. Sub-recent time-averaged samples were collected from 2 fringing reefs in Almirante Bay $\left(9.3619^{\circ} \mathrm{N}, 82.2799^{\circ} \mathrm{W}\right.$; $9.3361^{\circ} \mathrm{N}, 82.2561^{\circ} \mathrm{W}$ ) using SCUBA. At both reefs, 4 replicate $10 \mathrm{~kg}$ bulk samples of fine sediments were excavated from the uppermost $10 \mathrm{~cm}$ in patches of mud, silt, and sand adjacent to live coral. An in situ fossil reef on Isla Colón $\left(9.3603^{\circ} \mathrm{N}, 82.2730^{\circ} \mathrm{W}\right)$ dating between 7.2 and $5.7 \mathrm{ka}$ (Fredston-Hermann et al. 2013) was sampled comparably, with 3 replicate $10 \mathrm{~kg}$ bulk samples collected from 3 localities characterized by branching Acropora or Porites coral. In total, 8 modern samples and 9 fossil samples were collected.

Samples were processed following the approach of Sibert et al. (in press) to extract dermal denticles with as little damage as possible. Sediments were dried, weighed, and sieved. The $106 \mu \mathrm{m}$ to $2 \mathrm{~mm}$ size fraction was then digested with $10 \%$ glacial acetic acid. After several acid rinses to eliminate the calcitic and aragonitic components, the remaining particles were treated with 100 to $200 \mathrm{ml} 5 \%$ hydrogen peroxide and heated for no more than $15 \mathrm{~min}$ to remove organic material. All denticles were manually picked from the residue with a paintbrush. They were photographed, counted, measured, and identified to functional morphotype and family using the reference collection.

\section{RESULTS AND DISCUSSION}

\section{Dermal denticle reference collection}

Denticle characters correlate to shark ecology

PCA Axis 1 and 2 explained 34.7 and $19.1 \%$ of the variation in denticle morphology, respectively (Fig. 4). The characters that had the highest explanatory power in the PCA were crown shape, the presence of ridges and multiple peaks, the types of peaks, ridge spacing, and whether the ridges were complete (Table 3). The first PC axis largely described the dif- 

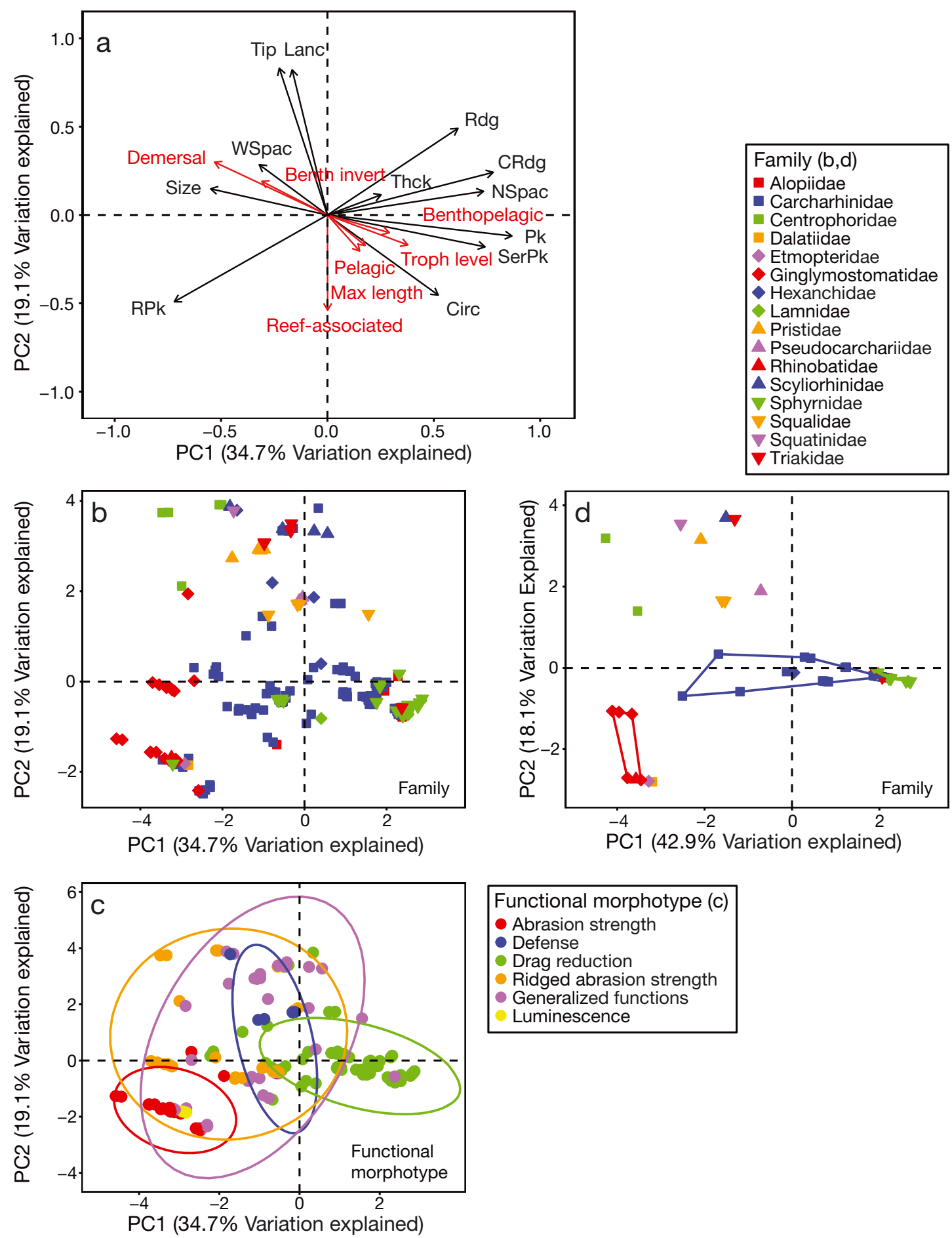

Fig. 4. Principal component analysis (PCA) performed on 12 denticle characters in the reference collection. (a) Correlation circle of characters (black) with ecological attributes overlaid a priori (red). Abbreviations of characters are those shown in Table 3; the ecological attributes of each species sampled are reported in Table 1. All denticles in the reference collection (Table S1 in the Supplement) were included in the analysis, and each is represented by a point in the ordination. The colours designating the shark families in panels (b) and (d) do not correspond with those designating the functional morphotypes in panel (c). (b) PCA scores labeled with respect to family. (c) PCA labeled with respect to functional morphotype, with $95 \%$ prediction ellipses shown. (d) Results of a separate PCA performed on the same characters using only denticles located on the trunk of the body. The PCA scores are labeled with respect to family, and convex hulls of the reef-associated families Carcharhinidae, Ginglymostomatidae, and Sphyrnidae are shown 

sis (PCA). Characters were selected from Table 2 based on their percent contribution to principal components (PC) 1 and 2. The crown thickness ratio, while contributing little to PC1 and PC2, was found to be useful when distinguishing between groups, and was therefore included in the analysis. Abbreviations are used to present the results of the analysis graphically in Fig. 4A

\begin{tabular}{|lccc|}
\hline Character & $\begin{array}{c}\text { Abbrevia- } \\
\text { tion }\end{array}$ & $\begin{array}{c}\text { PC1 \% } \\
\text { contribution }\end{array}$ & $\begin{array}{c}\text { PC2 \% } \\
\text { contribution }\end{array}$ \\
\hline Circular or elliptical crown shape & Circ & 6.52 & 8.92 \\
Lanceolate or teardrop crown shape & Lanc & 0.66 & 29.48 \\
Crown size & Size & 7.24 & 0.96 \\
Crown thickness ratio & Thck & 1.53 & 0.57 \\
$>1$ peak present & Pk & 18.08 & 0.62 \\
Rounded peaks or single V-shaped & RPk & 12.46 & 10.51 \\
peak & & & \\
Distinct serrated peaks & SerPk & 13.20 & 1.41 \\
Peak edges curve inward to form & Tip & 1.23 & 30.12 \\
single tip & & & \\
$\geq 1$ ridge present & Rdg & 9.05 & 10.49 \\
Complete ridges & CRdg & 14.6 & 2.55 \\
1 to $100 \mu$ m ridge spacing & NSpac & 12.95 & 0.78 \\
$>100 \mu$ m ridge spacing & WSpac & 2.47 & 3.54 \\
\hline
\end{tabular}

Table 3. Dermal denticle characters included in the principal component analy-

across individuals and species (Figs. 2B \& 4B, Table S2). There was minor overlap between the coastal families Carcharhinidae, Ginglymostomatidae, Sphyrnidae, Alopiidae, and Lamnidae, whose denticles could plausibly accumulate in reef sediments. The discrimination between these groups, however, was more pronounced when only the denticles found on the trunk of the bodywhich cover the greatest surface area of the skin and are the most likely to enter the fossil recordwere included in the analysis (Fig. 4D). Carcharhinidae covered a wide area in PC space; this is possibly due to the high diversity of ecological guilds occupied by species within this family, although it could also be an artifact of the large number of species sampled relative

ference between highly ridged denticles with narrow ridge spacing and multiple peaks and smooth denticles with a single peak. The second PC axis described differences in crown shape, namely pointed, teardropshaped denticles as opposed to rounded denticles.

Morphological variation in PC space had high correspondence with the ecological attributes of the shark species (Fig. 4A). For example, demersal sharks typically possess either large, thick, unridged denticles with a single rounded peak (i.e. abrasion strength) or ridged, lanceolate denticles (i.e. ridged abrasion strength and generalized functions). Pelagic and benthopelagic sharks possess circular denticles with several complete, narrowly-spaced ridges and multiple peaks (i.e. drag reduction). These ridges improve hydrodynamic efficiency by disrupting the boundary layer between the skin and surrounding water, reducing turbulence as water flows around the shark's body (Reif \& Dinkelacker 1982, Raschi \& Musick 1986, Dean \& Bhushan 2010, Lang et al. 2012, Díez et al. 2015). PCA of denticle morphology also revealed high co-correlation between trophic level, maximum length, and life mode, strongly supporting the use of morphological characters to broadly predict shark ecology (Fig. 4A).

Shark families share denticle characters

Shark families overlapped extensively in PC space due to the high diversity of denticle forms found to other families. Sphyrnidae, Lamnidae, and Alopiidae clustered together and overlapped slightly with Carcharhinidae, which is likely due to the functional similarities between these groups (Muñoz-Chápuli 1985a, Reif 1985a, Mello et al. 2013). In contrast, the denticles on the body of Ginglymostomatidae were separate in PC space due to their characteristic thick crowns and V-shaped peaks (Fig. 4D).

Ridge spacing (Fig. 1) was found to be useful in distinguishing between morphologically similar denticles belonging to Carcharhinidae, Ginglymostomatidae, Sphyrnidae, Alopiidae, and Lamnidae. Ridge spacing has previously been correlated with swimming speed, with narrower ridges conferring hydrodynamic advantage at faster speeds (Reif \& Dinkelacker 1982, Raschi \& Elsom 1986, Raschi \& Musick 1986), and has been used to define ecological swimming groups (Reif 1985a). In fast swimming species, ridge spacing has also been found to remain constant despite the positive correlation between denticle and body size (Reif 1985a, Raschi \& Musick 1986). We found Sphyrnidae, Lamnidae, and Alopiidae to have narrowly-spaced ridges, in concordance with their fast burst speeds (Raschi \& Musick 1986, Froese \& Pauly 2016). Their ridge spacing was significantly smaller than Carcharhinidae, which in turn had smaller spacing than Ginglymostomatidae (ANOVA, $F_{4,145}=33.25$, p < 0.0001; Fig. 5, Table S3). Again, this pattern was stronger when only denticles on the trunk of the body were considered, as some denticles on the fins had uniformly narrow spacing 


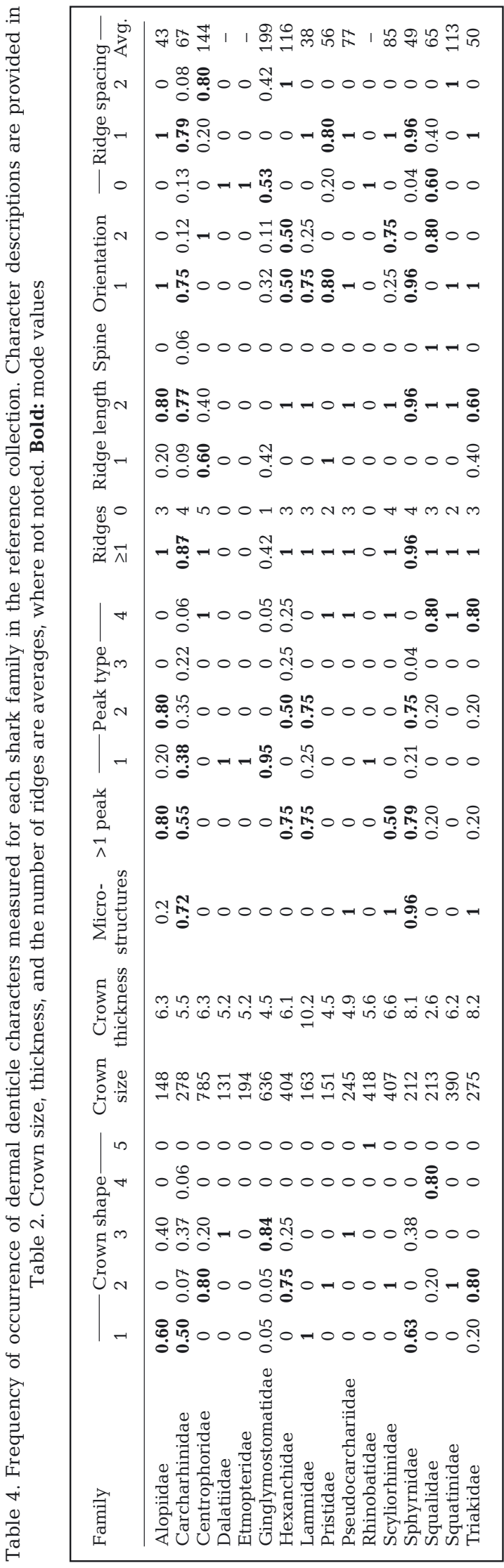

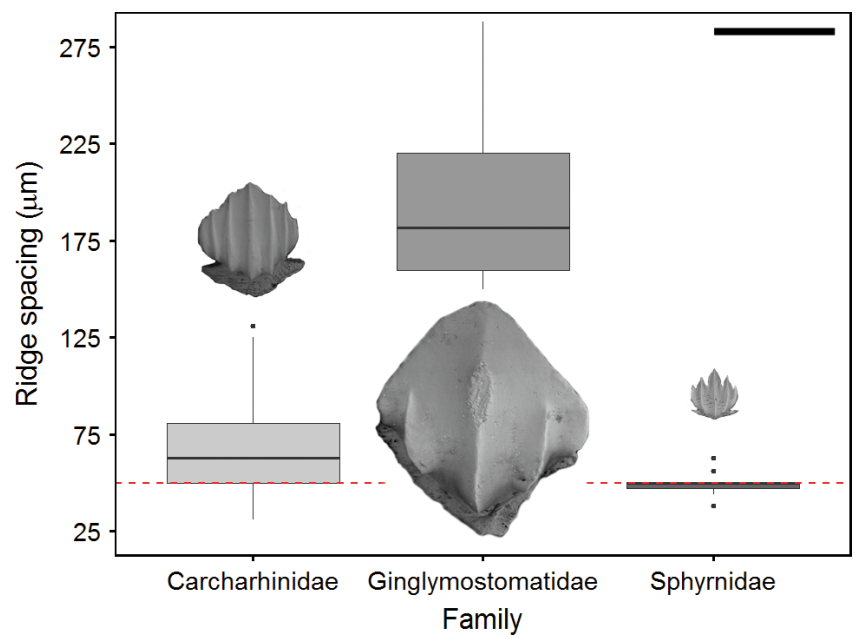

Fig. 5. Boxplots of ridge spacing for the reef-associated families in the reference collection. Distances were measured between the central ridge and adjacent medial ridge on the crown (Fig. 1). Only denticles possessing ridges were included in the analysis. Ginglymostomatidae $(\mathrm{n}=8)$ possessed much wider ridge spacing than Carcharhinidae $(\mathrm{n}=110)$ and Sphyrnidae $(\mathrm{n}=23)(\mathrm{p}<$ 0.0001). Ridge spacing in Carcharhinidae was also significantly wider than in Sphyrnidae $(\mathrm{p}=0.005)$. Denticles with ridge spacing $<50 \mu \mathrm{m}$ (dotted line) were only found on the fins in Carcharhinidae and Sphyrnidae. Scale bar $=500 \mu \mathrm{m}$

across families (Fig. 5). We conclude that ridge spacing, with some degree of confidence, can aid the taxonomic identification at the family level of isolated denticles possessing ridges that are indistinguishable by other characters.

In addition to ridge spacing, crown size and microstructures can be used to help differentiate between Carcharhinidae, Sphyrnidae, Alopiidae, and Lamnidae (Table 4). The crown size of Carcharhinidae was significantly larger than Sphyrnidae, Alopiidae, and Lamnidae (ANOVA, $F_{3,156}=12.65, \mathrm{p}<0.0001$; Tukey's HSD, $\mathrm{p}<0.05$; Table S3). Furthermore, a higher proportion of denticles in Sphyrnidae (96\%) and Carcharhinidae (72\%) had prominent microstructures - which are thought to play a fine-scale hydrodynamic role (Muñoz-Chápuli 1985b, Mello et al. 2013) - on their crowns than denticles in Alopiidae (20\%) and Lamnidae (0\%) (Table 4).

\section{Characters quantitatively define boundaries between functional morphotypes}

The PCA corroborated the existing qualitative descriptions of functional morphotypes established by Reif (1985a) and reviewed in Raschi \& Tabit (1992) while quantitatively refining the boundaries between them and identifying areas of overlap (Fig. 4C). The $95 \%$ prediction ellipses for drag reduction and abrasion strength denticles 


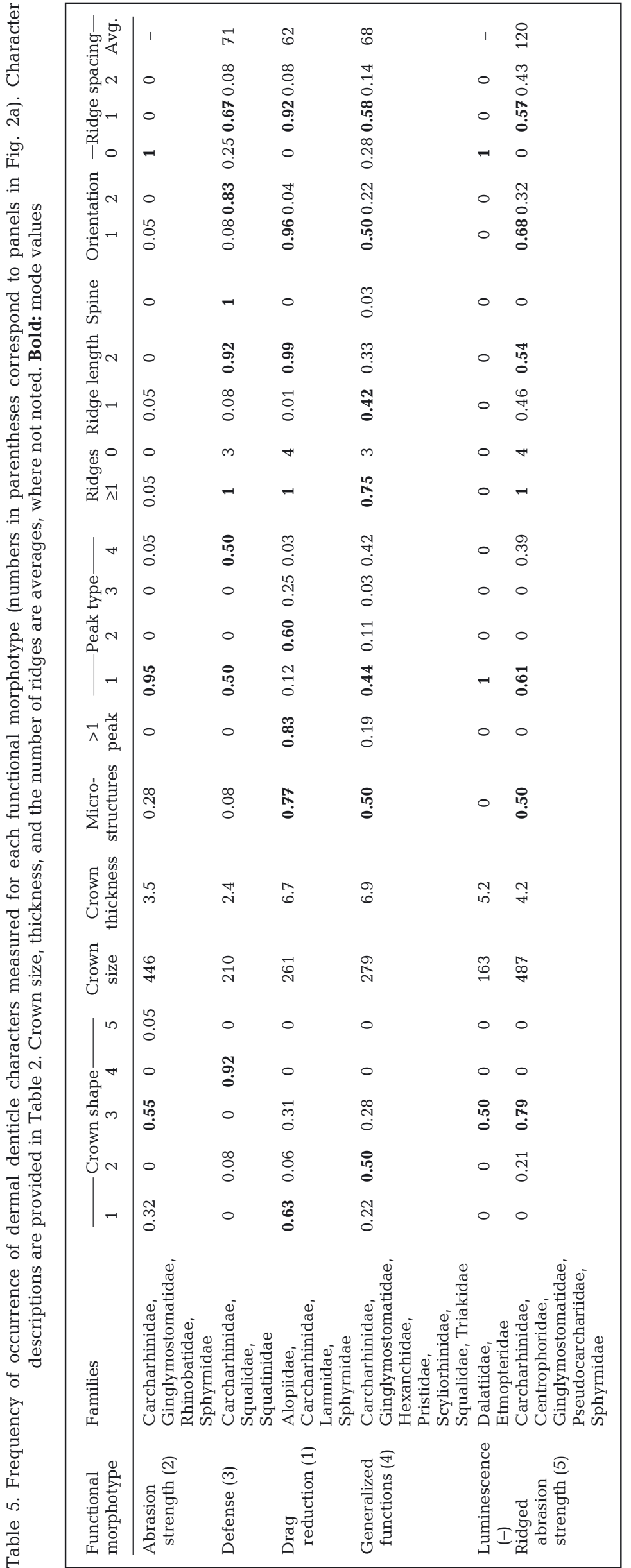

were completely separate, and the $95 \%$ prediction ellipse for ridged abrasion strength denticles overlapped with both constituent groups. Generalized functions denticles covered a broad area in the center of PC space, given their range of characters and functions. However, crown thickness can be used to distinguish between thinner generalized functions or drag reduction denticles and thicker abrasion strength or ridged abrasion strength denticles (ANOVA, $F_{5,209}=25.83, \mathrm{p}$ $<0.0001$; Tukey's HSD, $\mathrm{p}<0.0001$; Table S3). Furthermore, drag reduction denticles can be differentiated from generalized functions denticles, as the former typically possess a larger number of complete, parallel ridges ending in peaks of equal height (Table 5). The $95 \%$ prediction ellipse for defense denticles overlapped almost entirely with ridged abrasion strength denticles in PC space, although they can be distinguished by the upward-pointing, spine-shaped crowns (Fig. 2A, Table 5).

\section{Proof of concept: reef sediments contain well-preserved denticles}

A total of 330 denticles (240 modern, 90 fossil) were extracted from the bulk samples of reef sediments. On average, 50.4 denticles $( \pm 24.5 \mathrm{SD})$ were recovered per $10 \mathrm{~kg}$ of the $63 \mu \mathrm{m}$ to $2 \mathrm{~mm}$ size fraction. Denticles ranged from approximately $100 \mu \mathrm{m}$ to $1 \mathrm{~mm}$ in size, and were predominantly collected in the $250 \mu \mathrm{m}$ to $2 \mathrm{~mm}$ size fraction, with only $8 \%$ of the denticle assemblage found in the 106 to $250 \mu \mathrm{m}$ size fraction. The vast majority of denticles $(86.0 \%)$ were intact and wellpreserved (Fig. 6). We found that just 13.3\% of modern and $2.2 \%$ of fossil denticles were too poorly preserved to allow clear classification or measurement. The drag reduction, abrasion strength, and ridged abrasion strength morphotypes comprised $84.5 \%$ of the overall denticle assemblage. These functional morphotypes corresponded with the reef-associated families Carcharhinidae, Ginglymostomatidae, and Sphyrnidae (Fig. 2B, Tables $5 \& \mathrm{~S} 2$ ), which are reported in the Bocas del Toro Archipelago (Robertson \& Van Tassell 2015). While drag reduction denticles are also possessed by the pelagic 


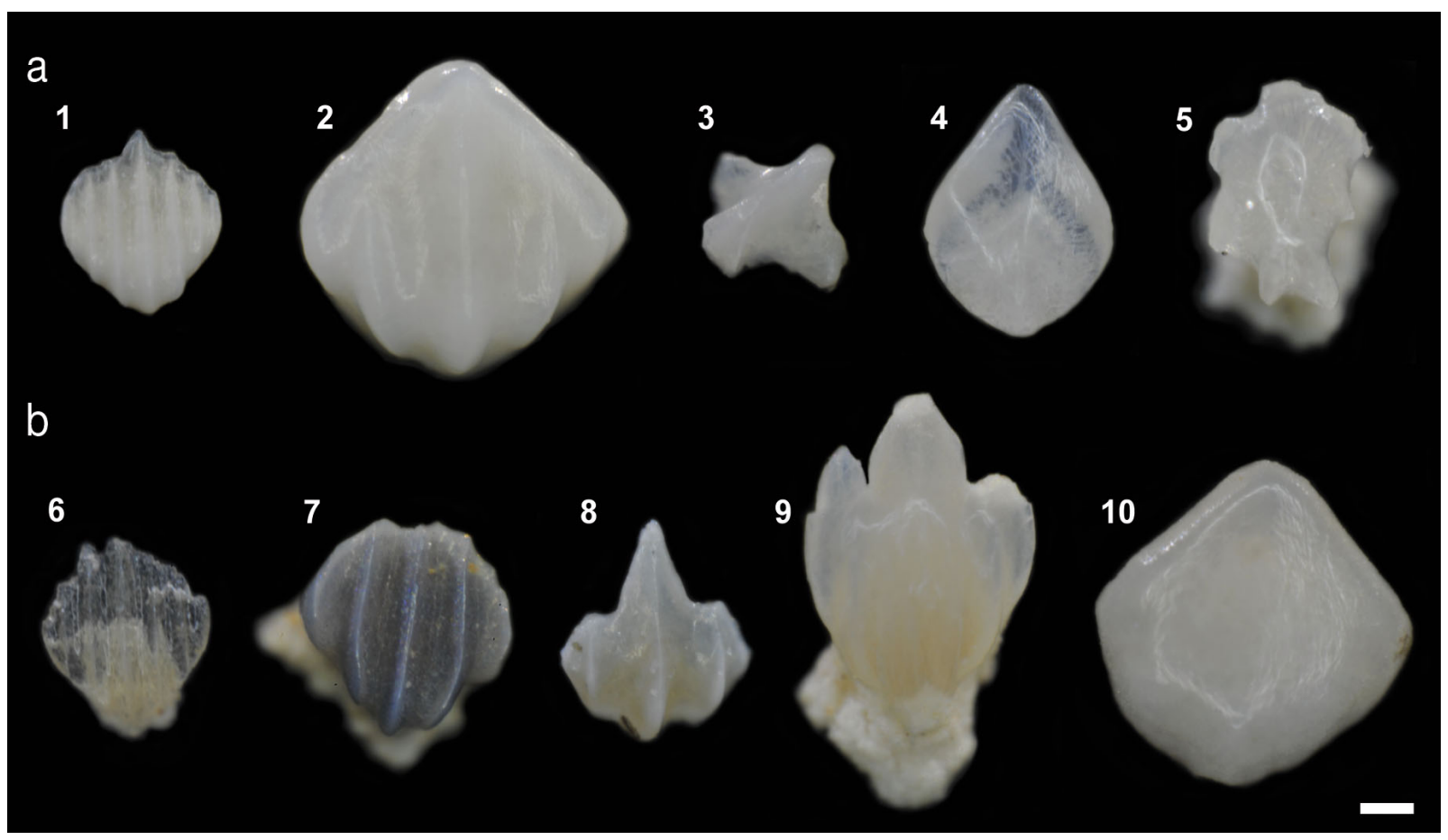

Fig. 6. Examples of dermal denticles extracted from (a) modern and (b) fossil reefs in Bocas del Toro, Panama. Functional morphotypes and predicted families: (1) drag reduction, Carcharhinidae; (2) ridged abrasion strength, Ginglymostomatidae; (3) defense, Squalidae?; (4) generalized functions, Ginglymostomatidae; (5) abrasion strength, family unknown; (6) drag reduction, Carcharhinidae; (7) ridged abrasion strength, Carcharhinidae; (8) generalized functions, family unknown; (9) generalized functions, Carcharhinidae?; (10) abrasion strength, Ginglymostomatidae. Denticles with unknown family classifications did not match up to examples in the reference collection. Scale bar $=100 \mu \mathrm{m}$

families Alopiidae and Lamnidae (Tables 1, 5 \& S2), these taxa have not been observed inshore in Caribbean Panama (Robertson \& Van Tassell 2015), so we consider them unlikely contributors to these reef assemblages.

Generalized functions denticles were present in small numbers in both modern and fossil sediments, composing $10.4 \%$ and $18.9 \%$ of their respective denticle assemblages. In the reference collection, this morphotype was uncommon in reef-associated families (Table 5). It was found only on small sections of the fins in Carcharhinidae and very sparsely on the body, fins, and gill slits in Ginglymostomatidae (Fig. 2B, Table S2).

Three defense denticles were found in the modern reef sediments. In the reference collection, this morphotype was found on the bodies of mesopelagic sharks (Fig. 2C, Tables 5 \& S2), which have not been observed on the lagoonal reefs of the Bocas del Toro Archipelago. However, the tiger shark Galeocerdo cuvier also possesses distinctive defense type denticles (Fig. 2B), and its presence in Almirante Bay was corroborated by a tooth discovered at the fossil reef. Two of the 3 denticles extracted from the modern reefs were morphologically similar to denticles belonging to G. cuvier in the reference collection and were thus likely to have been shed by this species.

Predictably, luminescence denticles were not observed in the modern nor fossil reef sediments, as they were possessed only by mesopelagic species in the reference collection (Table 5). Less than $15 \%$ of the denticles found in the sediments could not be attributed to examples in our reference collection, suggesting the infrequent presence of pelagic or undocumented species. Alternatively, they may have originated from obscure anatomical positions that were not included in our reference collection, such as the nictitating membrane, oral cavity, or pit organs (Reif 1985a).

\section{Potential applications}

Morphometric analysis as a denticle classification tool

The measurement and categorization of denticle characters constitute a quantitative and consistent 
Table 6. A comparative summary of shark survey methods. 'Taxonomic resolution' describes the commonly reported taxonomic levels, which often correspond to the highest possible taxonomic resolution for each survey method. CPUE: catch per unit effort

\begin{tabular}{|c|c|c|c|c|}
\hline Technique & $\begin{array}{l}\text { Common measurement } \\
\text { metrics }\end{array}$ & Time frame & $\begin{array}{l}\text { Taxonomic } \\
\text { resolution }\end{array}$ & Selected citations \\
\hline $\begin{array}{l}\text { Diver surveys (e.g. belt transects, } \\
\text { timed surveys, point counts) }\end{array}$ & Abundance, density, biomass & Hours & Species & $\begin{array}{l}\text { Sandin et al. (2008), } \\
\text { McCauley et al. } \\
(2012 \mathrm{a})\end{array}$ \\
\hline $\begin{array}{c}\text { Citizen science diver observations } \\
\text { (e.g. REEF) }\end{array}$ & $\begin{array}{l}\text { Sighting frequency, density, } \\
\text { individual observations }\end{array}$ & Hours & Species, family & $\begin{array}{l}\text { Ward-Paige et al. } \\
\qquad(2010 \mathrm{~b})\end{array}$ \\
\hline $\begin{array}{l}\text { Baited remote underwater videos } \\
\text { (BRUVs) }\end{array}$ & $\begin{array}{l}\text { maxN (max number of sharks } \\
\text { in one video frame) }\end{array}$ & Hours & Species & $\begin{array}{l}\text { Brooks et al. (2011), } \\
\text { White et al. (2013), } \\
\text { Espinoza et al. } \\
(2014)\end{array}$ \\
\hline Aerial surveys (e.g. drones) & $\begin{array}{l}\text { Abundance, density, sighting } \\
\text { frequency (per unit effort) }\end{array}$ & Hours & $\begin{array}{c}\text { Species } \\
\text { (restricted to } \\
\text { shallow, clear } \\
\text { waters or surface } \\
\text { swimmers) }\end{array}$ & Rowat et al. (2009) \\
\hline Environmental DNA (eDNA) & $\begin{array}{c}\text { Presence/absence, } \\
\text { abundance (DNA/amount } \\
\text { water) }\end{array}$ & $\begin{array}{l}\text { Days - } \\
\text { weeks }\end{array}$ & Species & Miya et al. (2015) \\
\hline Longline surveys & $\begin{array}{l}\text { Abundance (catch rate per } \\
\text { unit effort [soak time, number } \\
\text { and type of hooks, hook } \\
\text { depth]), biomass }\end{array}$ & $\begin{array}{l}\text { Months - } \\
\text { years }\end{array}$ & Species & $\begin{array}{c}\text { Baum \& Myers } \\
(2004) \text {, Myers et al. } \\
\text { (2007) }\end{array}$ \\
\hline $\begin{array}{l}\text { Landings statistics (e.g. Food and } \\
\text { Agriculture Organization of the } \\
\text { United Nations, FAO), fisheries } \\
\text { observer programs }\end{array}$ & $\begin{array}{l}\text { Tonnes caught, tonnes caught } \\
\mathrm{km}^{-2}, \text { CPUE }\end{array}$ & $\begin{array}{l}\text { Months - } \\
\text { years }\end{array}$ & $\begin{array}{l}\text { Species }(\sim 15 \%) \text {, } \\
\text { family, 'sharks } \\
\text { and rays' }\end{array}$ & $\begin{array}{l}\text { Bonfil (1997), Dulvy } \\
\text { \& Reynolds (2002), } \\
\text { Clarke et al. (2006) }\end{array}$ \\
\hline $\begin{array}{c}\text { Mark and recapture studies (e.g. } \\
\text { tagging) }\end{array}$ & $\begin{array}{l}\text { Survival and recapture } \\
\text { probability, population size }\end{array}$ & Years & Species & $\begin{array}{l}\text { Bradshaw et al. } \\
\text { (2007), MacNeil et } \\
\text { al. (2008) }\end{array}$ \\
\hline $\begin{array}{l}\text { Genetics (e.g. microsatellites, } \\
\text { mtDNA) }\end{array}$ & Population size and dynamics & $\begin{array}{c}\text { Generations, } \\
\text { years }\end{array}$ & Species & $\begin{array}{l}\text { Vignaud et al. } \\
\qquad(2014)\end{array}$ \\
\hline Logbooks and artifacts & $\begin{array}{l}\text { Qualitative or anecdotal } \\
\text { abundance, } \\
\text { presence/absence, sighting } \\
\text { frequency, biomass }\end{array}$ & $\begin{array}{l}\text { Years - } \\
\text { centuries; } \\
\text { historical } \\
\text { periods }\end{array}$ & $\begin{array}{c}\text { Species } \\
\text { (occasionally), } \\
\text { genus/family, } \\
\text { 'sharks and rays' }\end{array}$ & $\begin{array}{c}\text { Ferretti et al. (2008), } \\
\text { McClenachan } \\
\text { (2009), Drew et al. } \\
\text { (2013) }\end{array}$ \\
\hline Dermal denticle assemblages & $\begin{array}{c}\text { Abundance } \\
\text { (denticles/amount } \\
\text { sediment/time) }\end{array}$ & $\begin{array}{l}\text { Years - } \\
\text { centuries }\end{array}$ & $\begin{array}{c}\text { Family, } \\
\text { ecological guild }\end{array}$ & This study \\
\hline
\end{tabular}

framework with which to group isolated denticles extracted from reef sediments. Specifically, these measurements could serve as a powerful, objective denticle classification tool in conjunction with a discriminant analysis or machine learning program. While taxonomic identification, particularly beyond the family level, is generally constrained due to shared morphological characters and large variation across individuals and species, this method may distinguish between functional groups of denticles. Functional morphotypes reflect ecological guilds of sharks as opposed to the species-level data reported in existing census methods (Table 6). While seemingly limited in scope, such data can be very powerful in exploring community change at a mechanistic level (McGill et al. 2006).

\section{Setting quantitative shark baselines}

While considerable anecdotal, historical, and ecological evidence suggests that sharks were previously present in numbers unheard of today, it is likely that population assessments began after the initial degradation of marine ecosystems (Colón 1959, Pauly 1995, Jackson et al. 2001, Pandolfi et al. 2003, Knowlton \& Jackson 2008, Ferretti et al. 2008, Lotze $\&$ Worm 2009). Over the last 20 to $60 \mathrm{yr}$, longline surveys, commercial fishery observer programs, and fishery landings statistics (Table 6) have documented declines of $>50 \%$ in many shark species (Baum et al. 2003, Myers et al. 2007, Ferretti et al. 2010). However, issues with misreporting (especially of bycatch), misidentification, gear biases, and data resolu- 
tion undermine these estimates of population status (Burgess et al. 2005, Clarke et al. 2006, Dulvy et al. 2008). Written accounts, ship logbooks, and artifacts, although often qualitative or isolated in time and space, provide the only indication of shark abundance before this period (Holden 1977, Ferretti et al. 2008, Drew et al. 2013; Table 6). More empirical data is therefore needed to characterize unfished shark communities. We propose that denticle assemblages extracted from fossil reefs can help characterize missing region-specific pre-human shark baselines. They can also be used to explore how dynamic these baselines are. Moreover, shifts in the relative abundance of different denticle morphotypes over time may reveal changes in shark communities and, consequently, alterations in community function through sharks' trophic and behaviorally mediated impacts on prey (Bascompte \& Melia 2005, Heithaus et al. 2008, McCauley et al. 2012b, Heupel et al. 2014, Frisch et al. 2016).

\section{Surveying modern shark communities}

On coral reefs, traditional fish surveys using diver transects or videos represent 'snapshots' of the standing population and, as such, can overlook rare, cryptic, nocturnal, or seasonally-ephemeral species (Sale \& Douglas 1981, Edgar et al. 2004, MacNeil et al. 2008, McCauley et al. 2012a; Table 6). They also lack the temporal resolution of some fishery-dependent records, and fail to capture natural fluctuations in populations over time (Connell et al. 1998, MacNeil et al. 2008). Consequently, estimates of top predator biomass at the same study sites often differ substantially (DeMartini et al. 2008, Sandin et al. 2008, Williams et al. 2011, Nadon et al. 2012). In contrast, time-averaged assemblages of denticles in bulk sediment samples are a product of the accumulation of denticles shed from the long-term shark community (c.f. Vermeij \& Herbert 2004, Kidwell 2008, 2013, Kosnik \& Kowalewski 2016; Table 6). This has clear benefits in regions such as Bocas del Toro, where sharks are rarely or never reported (e.g. DominiciArosemena \& Wolff 2005; see also the website of the Reef Environmental Education Foundation, www.reef.org) yet leave a significant record of their presence in the form of denticles preserved in reef sediments. Based on predictions of shark species distributions in the Bocas del Toro Archipelago (Robertson \& Van Tassell 2015), our findings suggest that the denticle record has a basic level of fidelity with the living shark community, supporting the use of denti- cles as a register of relative shark abundance and community composition. We therefore propose that denticle assemblages offer a new approach to measuring relative shark abundance on modern reefs, and can supplement existing surveys if the limitations of the approach are respected.

\section{Limitations and considerations}

If denticle assemblages in sediments are to be used to reconstruct shark communities, we must explore the taphonomic processes involved in the accumulation of denticles in sediments and the limitations of the approach.

\section{Mechanism of denticle accumulation on reefs}

Denticles are continually shed over a shark's lifetime by either rubbing off or through resorption of the anchoring fibers attached to the base (Reif 1985a). After being shed, we propose that denticles are transported by currents or turbulence as they sink to the seabed. In calm conditions, shed denticles would quickly be incorporated into the accumulating sediment. Denticles could also reach the sediment post-mortem, although a carcass would be expected to produce dense patches of morphologically similar denticles, a pattern which was not observed in any of our bulk samples. Predation, ingestion, and defecation may be another route by which denticles could arrive at the sediment. If this occurs, denticles could potentially be transported long distances. However, we consider this a relatively rare process given that most sharks are meso- or apex-predators.

The density of denticles incorporated into a unit of sediment is controlled by (1) the number of sharks in the area, (2) the rate of denticle shedding on each shark, and (3) the rate of sediment accumulation. To assess the fidelity and resolution of the denticle record, comparisons between visual shark surveys and their corresponding denticle assemblages in bulk samples could enlighten our understanding of how denticles accumulate in sediments from living shark communities. Sharks are presently so rare on the reefs we studied, however, that a fidelity study would be meaningless. We recommend conducting such a study on reefs with large numbers of sharks and sufficient survey data, such as Palmyra Atoll (Sandin et al. 2008). Finally, denticle shedding rates are likely to vary between taxa and species' life habits. For example, demersal species frequently associated with abrasive 
coral may shed more denticles by mechanical abrasion than pelagic species.

\section{Temporal and spatial considerations of denticle accumulation}

The temporal scale of time averaging is influenced by the rate of sediment accumulation as well as bioturbation or other mixing (Kidwell \& Bosence 1991, Kidwell \& Flessa 1995). Deep sea, lagoonal, reef matrix, and anoxic sediments have low levels of bioturbation, making them most likely to preserve short timescales of ecological communities, whereas more heavily mixed sediments best represent long-term estimates of communities (Kosnik \& Kowalewski 2016). However, assuming quick burial and no postburial transportation of sediments, which can often be easily detected in the fossil record, denticle assemblages are likely to have an equally wide spatial scale as living shark communities.

\section{Sediment reworking and sorting}

Water energy may transport, sort, and rework denticles after they accumulate in the substrate. The specific density of dentine and enamel ( 2.1 and $3.0 \mathrm{~g}$ $\mathrm{ml}^{-1}$, respectively) is similar to that of calcite and aragonite $\left(2.7\right.$ and $2.8 \mathrm{~g} \mathrm{ml}^{-1}$, respectively), so we would expect denticles to be affected by these erosional and depositional processes to the same degree as other microfossils in the same size range, such as foraminifera. Careful selection of low energy, sheltered sites that show no evidence of large storms and currents reduces the likelihood that the assemblages have been sorted or reworked. For example, we limited our preliminary study to sediments deposited in a semi-enclosed lagoon where currents and wave action are minimal.

\section{Selective preservation of denticles}

Environmental factors, such as wave action and water chemistry, can affect microfossil preservation (Kidwell \& Flessa 1995), although ichthyoliths tend to be resistant to preservation biases (Helms \& Riedel 1971, Sibert \& Norris 2015). We observed that drag reduction denticles tended to fragment more easily than other denticle morphotypes, although this did not affect our ability to identify them. There was also no obvious superficial difference in the state of preservation between fossil and modern denticles. In fact, the proportion of fragmented denticles was higher in modern $(18.3 \%)$ than fossil $(3.3 \%)$ sediments, which may be because modern denticles are likely to be exposed for a longer period of time prior to burial due to the slow-down of coral reef accretion. Alternatively, if present, fossilized shark teeth may provide supplemental insight into the presence of pelagic sharks in the case that their drag reduction denticles are not well-preserved (Ferrón et al. 2014).

\section{SUMMARY}

The durable composition, high abundance on sharks' bodies, distinctive characteristics, and degree of preservation of dermal denticles support their use as a tool for reconstructing shark communities. We have shown that bulk sediment samples from modern and fossil reefs can yield sufficient numbers of well-preserved denticles to permit analysis. Denticle morphology can be used to taxonomically classify denticles, although the resolution is limited (typically family-level) except in a few groups (e.g. the tiger shark Galeocerdo cuvier and nurse shark Ginglymostoma cirratum). Conversely, denticle morphology is highly correlated with function and shark life mode. As such, the relative abundance of different denticle functional groups can yield powerful ecological information about the shark communities that contribute to the denticle record. We recommend further study of the processes of denticle shedding and accumulation, with particular focus on the fidelity of the denticle record to living shark communities. This new source of data may offer valuable insight into past and present shark communities, facilitating important assessments of the magnitude and ecological impacts of global shark declines and producing more meaningful conservation targets.

Acknowledgements. We thank F. Rodriguez, M. Alvarez, M. Hynes, M. Łukowiak, S. Finnegan, P. Rachello-Dolmen, and E. Grossman for technical assistance in the field; the Bocas del Toro Research Station staff for their support; B. De Gracia, M. Alvarez, M. Pierotti, and F. Rodriguez for assistance in the lab; and K. Cramer and E. Sibert for advice. We thank the Smithsonian National Museum of Natural History Museum Support Center Division of Fishes staff, especially K. Murphy, E. Wilbur, S. Raredon, R. Gibbons, and collection manager J. Williams, for providing access to their ichthyology collections and K. Murphy for logistical arrangements. This research was supported financially by a STRI Short Term Fellowship, the Save Our Seas Foundation, and the Joyce and Mike Bytnar Fund to E.M.D. and the National System of Investigators (SENACYT) to A.O. Valerie and Bill Anders also supported this study, for which we are grateful. 


\section{LITERATURE CITED}

Applegate S (1967) A survey of shark hard parts. In: Gilbert P, Mathewson R, Rall D (eds) Sharks, skates, and rays. Johns Hopkins Press, Baltimore, MD, p 37-67

Bargar T, Thorson T (1995) A scanning electron microscope study of the dermal denticles of the bull shark, Carcharhinus leucas. J Aquaricult Aquat Sci 7:120-137

Bascompte J, Melia CJ (2005) Interaction strength combinations and the overfishing. Proc Natl Acad Sci USA 102: 5443-5447

Baum JK, Myers RA (2004) Shifting baselines and the decline of pelagic sharks in the Gulf of Mexico. Ecol Lett 7:135-145

Baum JK, Myers RA, Kehler DG, Worm B, Harley SJ, Doherty PA (2003) Collapse and conservation of shark populations in the Northwest Atlantic. Science 299: 389-392

Bonfil R (1997) Status of shark resources in the Southern Gulf of Mexico and Caribbean: implications for management. Fish Res 29:101-117

* Bradshaw CJA, Mollet HF, Meekan MG (2007) Inferring population trends for the world's largest fish from markrecapture estimates of survival. J Anim Ecol 76:480-489

Brooks EJ, Sloman KA, Sims DW, Danylchuk AJ (2011) Validating the use of baited remote underwater video surveys for assessing the diversity, distribution and abundance of sharks in the Bahamas. Endang Species Res 13: 231-243

Burgess GH, Beerkircher LR, Cailliet GM, Carlson JK and others (2005) Is the collapse of shark populations in the northwest Atlantic Ocean and Gulf of Mexico real? Fisheries 30:19-26

Clarke SC, McAllister MK, Milner-Gulland EJ, Kirkwood GP and others (2006) Global estimates of shark catches using trade records from commercial markets. Ecol Lett 9:1115-1126

Colón F (1959) The life of the Admiral Christopher Columbus by his Son, Ferdinand. Rutgers University Press, New Brunswick

Compagno L, Dando M, Fowler S (2005) Sharks of the world. HarperCollins, London

Connell SD, Samoilys MA, Smith MPL, Leqata J (1998) Comparisons of abundance of coral-reef fish: catch and effort surveys vs visual census. Aust J Ecol 23:579-586

* Crooks N, Babey L, Haddon WJ, Love AC, Waring CP (2013) Sexual dimorphisms in the dermal denticles of the lesserspotted catshark, Scyliorhinus canicula (Linnaeus, 1758). PLOS ONE 8:e76887

Dean B, Bhushan B (2010) Shark-skin surfaces for fluid-drag reduction in turbulent flow: a review. Philos T R Soc A 368:4775-4806

DeMartini EE, Friedlander AM, Sandin SA, Sala E (2008) Differences in fish-assemblage structure between fished and unfished atolls in the northern Line Islands, central Pacific. Mar Ecol Prog Ser 365:199-215

Díez G, Soto M, Blanco JM (2015) Biological characterization of the skin of shortfin mako shark Isurus oxyrinchus and preliminary study of the hydrodynamic behaviour through computational fluid dynamics. J Fish Biol 87: 123-137

Dominici-Arosemena A, Wolff M (2005) Reef fish community structure in Bocas del Toro (Caribbean, Panama): gradients in habitat complexity and exposure. Caribb J Sci 41: 613-637
Drew J, Philipp C, Westneat MW (2013) Shark tooth weapons from the 19th century reflect shifting baselines in central Pacific predator assemblies. PLOS ONE 8: e59855

* Dulvy NK, Reynolds JD (2002) Predicting extinction vulnerability in skates. Conserv Biol 16:440-450

* Dulvy NK, Baum JK, Clarke S, Compagno LJV and others (2008) You can swim but you can't hide: the global status and conservation of oceanic pelagic sharks and rays. Aquat Conserv 18:459-482

Edgar GJ, Barrett NS, Morton AJ (2004) Biases associated with the use of underwater visual census techniques to quantify the density and size-structure of fish populations. J Exp Mar Biol Ecol 308:269-290

Espinoza M, Cappo M, Heupel MR, Tobin AJ, Simpfendorfer CA (2014) Quantifying shark distribution patterns and species-habitat associations: implications of marine park zoning. PLOS ONE 9:e106885

Ferretti F, Myers RA, Serena F, Lotze HK (2008) Loss of large predatory sharks from the Mediterranean Sea. Conserv Biol 22:952-964

Ferretti F, Worm B, Britten GL, Heithaus MR, Lotze HK (2010) Patterns and ecosystem consequences of shark declines in the ocean. Ecol Lett 13:1055-1071

*Ferrón H, Pla C, Martínez-Pérez C, Escudero-Mozo MJ, Botella H (2014) Morphometric Discriminant Analysis of isolated chondrichthyan scales for palaeoecological inferences: the Middle Triassic of the Iberian Chain (Spain) as a case of study. J Iber Geol 40:87-97

* Fredston-Hermann AL, O'Dea A, Rodriguez F, Thompson WG, Todd JA (2013) Marked ecological shifts in seagrass and reef molluscan communities since the mid-Holocene in the southwestern Caribbean. Bull Mar Sci 89: 983-1002

Frisch AJ, Ireland M, Rizzari JR, Lönnstedt OM, Magnenat KA, Mirbach CE, Hobbs JPA (2016) Reassessing the trophic role of reef sharks as apex predators on coral reefs. Coral Reefs 35:459-472

Froese R, Pauly D (2016) FishBase. www.fishbase.org (accessed 12 Jan 2016)

Gilligan JJ, Otway NM (2011) Comparison of dorsal and pectoral fin denticles for grey nurse, great white, and six whaler sharks from east Australian waters. J Proc R Soc New South Wales 144:66-82

Heithaus MR, Frid A, Wirsing AJ, Worm B (2008) Predicting ecological consequences of marine top predator declines. Trends Ecol Evol 23:202-210

Helms PB, Riedel WR (1971) Skeletal debris of fishes. In: Winterer EL, Riedel WR, Brönnimann P, Gealy EL and others (eds) Initial reports of the deep sea drilling project, 7 (Part 2). US Government Printing Office, Washington, DC, p 1709-1720

* Heupel MR, Williams AJ, Welch DJ, Ballagh A and others (2009) Effects of fishing on tropical reef associated shark populations on the Great Barrier Reef. Fish Res 95: 350-361

*Heupel MR, Knip DM, Simpfendorfer CA, Dulvy NK (2014) Sizing up the ecological role of sharks as predators. Mar Ecol Prog Ser 495:291-298

Holden MJ (1977) Elasmobranchs. In: Gulland JA (ed) Fish population dynamics. John Wiley \& Sons, New York, NY, p 187-215

Jackson JBC, Kirby MX, Berger WH, Bjorndal KA and others (2001) Historical overfishing and the recent collapse of coastal ecosystems. Science 293:629-638 
Janvier P (1996) Early vertebrates. Oxford University Press, Oxford

Kidwell SM (2008) Ecological fidelity of open marine molluscan death assemblages: effects of post-mortem transportation, shelf health, and taphonomic inertia. Lethaia 41:199-217

Kidwell SM (2013) Time-averaging and fidelity of modern death assemblages: building a taphonomic foundation for conservation palaeobiology. Palaeontology 56:487-522

Kidwell SM, Bosence DWJ (1991) Taphonomy and timeaveraging of marine shelly faunas. In: Allison PA, Briggs DEG (eds) Taphonomy: releasing the data locked in the fossil record. Plenum Press, New York, NY, p 115-209

Kidwell SM, Flessa KW (1995) The quality of the fossil record: populations, species, and communities. Annu Rev Ecol Syst 26:269-299

Knowlton N, Jackson JBC (2008) Shifting baselines, local impacts, and global change on coral reefs. PLoS Biol 6: e54

Kosnik MA, Kowalewski M (2016) Understanding modern extinctions in marine ecosystems: the role of palaeoecological data. Biol Lett 12:20150951

Lang A, Habegger ML, Motta P (2012) Shark skin drag reduction. In: Bhushan B (ed) Encyclopedia of nanotechnology, Part 19. Springer, Berlin, p 2394-2400

Lotze HK, Worm B (2009) Historical baselines for large marine animals. Trends Ecol Evol 24:254-262

MacNeil MA, Graham NAJ, Conroy MJ, Fonnesbeck CJ and others (2008) Detection heterogeneity in underwater visual-census data. J Fish Biol 73:1748-1763

McCauley DJ, McLean KA, Bauer J, Young HS, Micheli F (2012a) Evaluating the performance of methods for estimating the abundance of rapidly declining coastal shark populations. Ecol Appl 22:385-392

* McCauley DJ, Young HS, Dunbar RB, Estes JA, Semmens BX, Micheli F (2012b) Assessing the effects of large mobile predators on ecosystem connectivity. Ecol Appl 22:1711-1717

McClenachan L (2009) Documenting loss of large trophy fish from the Florida Keys with historical photographs. Conserv Biol 23:636-643

McGill BJ, Enquist BJ, Weiher E, Westoby M (2006) Rebuilding community ecology from functional traits. Trends Ecol Evol 21:178-185

Mello WC, de Carvalho JJ, Brito PMM (2013) Microstructural morphology in early dermal denticles of hammerhead sharks (Elasmobranchii: Sphyrnidae) and related taxa. Acta Zool 94:147-153

Miya M, Sato Y, Fukunaga T, Sado T and others (2015) MiFish, a set of universal PCR primers for metabarcoding environmental DNA from fishes: detection of more than 230 subtropical marine species. R Soc Open Sci 2:150088

Motta P, Habegger ML, Lang A, Hueter R, Davis J (2012) Scale morphology and flexibility in the shortfin mako Isurus oxyrinchus and the blacktip shark Carcharhinus limbatus. J Morphol 273:1096-1110

Muñoz-Chápuli R (1985a) Sobre la clasificación tipológica del esqueleto dérmico de escualos (Chondrichthyes). Misc Zool 9:396-400

Muñoz-Chápuli R (1985b) Ornamentación ultraestructural del esqueleto dérmico en algunas especies de Carcharhiniformes. Misc Zool 9:394-396

* Myers RA, Worm B (2003) Rapid worldwide depletion of predatory fish communities. Nature 423:280-283

Myers RA, Baum JK, Shepherd TD, Powers SP, Peterson CH
(2007) Cascading effects of the loss of apex predatory sharks from a coastal ocean. Science 315:1846-1850

Nadon MO, Baum JK, Williams ID, McPherson JM and others (2012) Re-creating missing population baselines for Pacific reef sharks. Conserv Biol 26:493-503

Odum HT, Odum EP (1955) Trophic structure and productivity of a windward coral reef community on Eniwetok Atoll. Ecol Monogr 25:291-320

*Pandolfi JM, Bradbury RH, Sala E, Hughes TP and others (2003) Global trajectories of the long-term decline of coral reef ecosystems. Science 301:955-958

*Pauly D (1995) Anecdotes and the shifting baseline syndrome of fisheries. Trends Ecol Evol 10:430

R Core Team (2014) R: a language and environment for statistical computing. R Foundation for Statistical Computing, Vienna

Raschi W, Elsom J (1986) Comments on the structure and development of the drag reduction-type placoid scale. In: Uyeno T, Arai R, Taniuchi T, Matsuura K (eds) Proc Second Int Conf on Indo-Pacific Fishes, Tokyo, Jul 29 to Aug 3 1985. Ichthyological Society of Japan, Tokyo, p 392-407

Raschi WG, Musick JA (1986) Hydrodynamic aspects of shark scales. National Aeronautics and Space Administration, Scientific and Technical Information Branch, Washington, DC

* Raschi W, Tabit C (1992) Functional aspects of placoid scales: a review and update. Aust J Mar Freshwater Res 43:123-147

Reif WE (1978) Protective and hydrodynamic function of the dermal skeleton of elasmobranchs. Neues Jahrb Geol Palaontol Abh 157:133-141

Reif WE (1982) Morphogenesis and function of the squamation in sharks. I. Comparative functional morphology of shark scales, and ecology of sharks. Neues Jahrb Geol Palaontol Abh 164:172-183

Reif WE (1985a) Squamation and ecology of sharks. Cour Forschungsinstitut Senckenb Band 78, Schweizerbart Science Publishers, Stuttgart

* Reif WE (1985b) Functions of scales and photophores in mesopelagic luminescent sharks. Acta Zool 66:111-118

Reif WE, Dinkelacker A (1982) Hydrodynamics of the squamation in fast swimming sharks. Neues Jahrb Geol Palaontol Abh 164:184-187

* Rizzari JR, Frisch AJ, Connolly SR (2014) How robust are estimates of coral reef shark depletion? Biol Conserv 176: 39-47

Robertson DR, Van Tassell J (2015) Shorefishes of the Greater Caribbean: online information system. http:// biogeodb.stri.si.edu/caribbean/en/pages (accessed on 11 Oct 2015)

Roff G, Doropoulos C, Rogers A, Bozec YM and others (2016) The ecological role of sharks on coral reefs. Trends Ecol Evol 31:395-407

* Rowat D, Gore M, Meekan MG, Lawler IR, Bradshaw CJA (2009) Aerial survey as a tool to estimate whale shark abundance trends. J Exp Mar Biol Ecol 368:1-8

* Sale PF, Douglas WA (1981) Precision and accuracy of visual census techniques for fish assemblages on coral patch reefs. Environ Biol Fishes 6:333-339

Salini J, Giles J, Holmes B, Last P and others (2007) Species identification from shark fins-Phase 1. Final report for Australian Fisheries Management Authority, Commonwealth Scientific and Industrial Research Organisation, Canberra 
Sandin SA, Smith JE, DeMartini EE, Dinsdale EA and others (2008) Baselines and degradation of coral reefs in the northern Line Islands. PLoS One 3:e1548

Sansom IJ, Davies NS, Coates MI, Nicoll RS, Ritchie A (2012) Chondrichthyan-like scales from the middle Ordovician of Australia. Palaeontology 55:243-247

Sibert EC, Norris RD (2015) New age of fishes initiated by the Cretaceous-Paleogene mass extinction. Proc Natl Acad Sci USA 112:8537-8542

Sibert EC, Cramer KL, Hastings PA, Norris RD (in press) Methods for isolation and quantification of microfossil fish teeth and shark dermal denticles (ichthyoliths) from marine sediments. Palaeontol Electronica

Tanaka S, Kitamura T, Nakano H (2002) Identification of shark species by SEM observation of denticle of shark fins. Col Vol Sci Pap ICCAT 54:1386-1394

Tway L (1979) A coded system for utilizing ichthyoliths of any age. Micropaleontology 25:151-159

Vermeij GJ, Herbert GS (2004) Measuring relative abundance in fossil and living assemblages. Paleobiology 30: $1-4$

Vignaud TM, Mourier J, Maynard JA, LeBlois R and others (2014) Blacktip reef sharks, Carcharhinus melanopterus, have high genetic structure and varying demographic histories in their Indo-Pacific range. Mol Ecol 23:5193-5207

Editorial responsibility: Rory Wilson,

Swansea, UK
Ward P, Myers RA (2005) Shifts in open-ocean fish communities coinciding with the commencement of commercial fishing. Ecology 86:835-847

*Ward-Paige C, Flemming JM, Lotze HK (2010a) Overestimating fish counts by non-instantaneous visual censuses: consequences for population and community descriptions. PLOS ONE 5:e11722

* Ward-Paige CA, Mora C, Lotze HK, Pattengill-Semmens C, McClenachan L, Arias-Castro E, Myers RA (2010b) Large-scale absence of sharks on reefs in the greaterCaribbean: a footprint of human pressures. PLOS ONE 5: e11968

WWite J, Simpfendorfer CA, Tobin AJ, Heupel MR (2013) Application of baited remote underwater video surveys to quantify spatial distribution of elasmobranchs at an ecosystem scale. J Exp Mar Biol Ecol 448:281-288

*Williams ID, Richards BL, Sandin SA, Baum JK and others (2011) Differences in reef fish assemblages between populated and remote reefs spanning multiple archipelagos across the Central and Western Pacific. J Mar Biol 2011: $1-14$

Williams ID, Baum JK, Heenan A, Hanson KM, Nadon MO, Brainard RE (2015) Human, oceanographic and habitat drivers of Central and Western Pacific coral reef fish assemblages. PLOS ONE 10:e0120516

Submitted: May 30, 2016; Accepted: December 14, 2016 Proofs received from author(s): February 19, 2017 